\title{
INTERCULTURAL AND MEDIA LITERACY: GLOBAL TENDENCIES IN METACONTENT OF TEACHER EDUCATION IN LATVIA
}

\author{
Inga Belousa and Alnis Stakle \\ Daugavpils University, Latvia
}

\begin{abstract}
Under the influence of processes of globalisation, higher education in the countries of Europe, including Latvia, has been reshaped, restructured, re-evaluated and reoriented towards the establishment of a European higher education area. New issues have emerged at both the content and metacontent level, the most significant of which are intercultural and media literacy matters. Considering the tendencies of globalisation, this article focuses on the issues of intercultural and media literacy as a metacontent of teacher education. The article introduces the teachers' view and experience of intercultural and media education in Latvia and frames several suggestions to implement intercultural and media literacy in the teacher education curriculum.
\end{abstract}

Key words: intercultural literacy, media literacy, metacontent of teacher education, globalisation

\section{Introduction}

The discourse about the balancing and harmonisation of national and global trends in education is rather prevalent. Such discourse is both philosophical and pragmatic as it presents challenges, highlights paradoxes and searches for practical solutions. Considering the phenomenon of constant change, educators can be assured that this discourse will resemble a never-ending story. No matter how much educators would argue that education should involve hands-on involvement and applied drive, a strong conceptual foundation is also needed in order to clarify and sustain responses to urgent issues and to create the educator's own competence-based position in order to ensure meaningful practice. Teacher training universities and other higher education institutions are the key initiators and providers of this conceptual discourse.

Globalisation is not a merely philosophical phenomenon. Sooner or later, this process will land on our own doorsteps and have essential influence on our daily lives. The net of challenges created by globalisation can be outlined as increased scope and interrelatedness of economic, social/cultural, political and ecological areas of life. As a single web of interrelated causal relationships, all the familiar global processes can be discerned, such as the internationalisation of business and marketing, the movement of financial capital, economic instability, human migration, awareness of the diverse social and cultural contexts, human segregation, climate change, the decrease of nature resources, ICT development, transfer of information, psychological insecurity and identity crisis, to mention but a few. Within the context of vast discussions about globalisation and its impacts in all the spheres of human activity, we cannot take these processes for granted. They urge us to admit that globalisation re-organises knowledge and changes thinking, 
participation and collaboration skills that are crucial for successful living. Thus, educators' awareness and creative involvement in the cognition of global processes, their local impact in education and educational response to them help them not only to review the foundations of their pedagogical mastery, but also to be active and successful authors of educational praxis and development.

\section{Globalisation of higher education in Latvia}

Entering into the European Union in May 1, 2004 has initiated the process of change in higher education in Latvia. The ongoing reforms are connected with the reorientation of higher education towards the principles of the Bologna Declaration and activities for creation of a "coherent and cohesive European Higher Education Area" (Realising the European Higher Education Area, 2003). The activities entitled the Bologna Process in Latvia is a continuation that "shapes the ongoing ones turning them into the overall stream of higher education reforms in Europe and often filling them with a new or changed content" (Rauhvargers, 2003, p. 19). This European trend initiates processes that represent reshaping and restructurisation of whole field of higher education, including teacher education.

The action lines included in the Bologna declaration have introduced joint objectives and constitutive areas that are crucial for the continuing advancement of higher education. The declaration and main reports on trends and the process of creating a European higher education area acknowledge that "higher education is a public good and a public responsibility" (Realising the European Higher Education Area, 2003, p. 1) - a constitutive area of shaping "the basis of the Europe of Knowledge" (p. 2), "promotion of the European dimension in higher education" (p. 6) and enhancing "the possibilities of lifelong learning" (p. 6). So, the aim together with the creation of a European higher education area is "to preserve Europe's cultural richness and linguistic diversity, based on its heritage of diversified traditions, and to foster its potential of innovation and social and economic development through enhanced co-operation among European Higher Education Institutions" (p. 2). These guidelines also refer to teacher education.

"The National Conception on the Development of Latvian Higher Education and Higher Educational Institutions for the Period until 2010" (Higher Education Council, 2001) is mandated to monitor the purposeful implementation of the action lines of the Bologna declaration. The strategic objective of this conception is to develop the Latvian higher education system with a view of, on the one hand, preserving its national development spirit and, on the other hand, readability and recognition of Latvian degrees and diplomas both for employment on the European labour market and further studies in Europe (Quoted in Rauhvargers, 2003, pp. 24-25).

The objective gives a legitimate hope that the stakeholders who coordinate the Bologna process in Latvia: Ministry of Education and Science with its dependent organisations/institutions - Rector's Council, Higher Education Council, Higher Education Quality Evaluation Centre, Academic Information Centre, Academic Programme Agency and higher education institutions will foster the dimension of education that facilitated the survival of the Latvian nation so that its uniqueness is in balance with global trends and can enrich the European higher education area.

The renovations of the structure of teacher education have necessitated the reforming of education content. Another global trend that initiates re-evaluation and reorientation of higher education in Latvia is influenced by the introduction of the strategy of sustainable development. This strategy has become the key criteria of success and 
effectiveness in all the spheres of society. In higher education it echoes the search for implementation of the aims of UN decade of education for sustainable development with the basic vision of the world where "everyone has the opportunity to benefit from education and learn the values, behaviour and lifestyles required for a sustainable future and for positive societal transformation" (UNESCO, 2005c, p. 6).

Three aspects of sustainability are identified as crucial - environment, society (including culture) and economy. All these aspects can be considered as lenses that make us aware of the broadness and complexity of the immediate environment and that encourage changes in our thinking, attitudes and behaviour in order to create a just society and a more sustainable future. Certainly, education reform alone will not accomplish this. It should take a broad and deep effort on the part of many sectors of society. However, education is the realm providing structured and purposeful activities to promote a holistic development of a person. Thus, it implies the message that education lies at the heart of the approach to sustainable development, that education is the key to sustainable development. Therefore, an essential role in the global education community is assigned to the institutions of teacher education - they have "the potential to bring changes within educational systems that will shape the knowledge and skills of future generations ... [they are] the key change agents in transforming education and society" (UNESCO, 2005a, p. 11).

The re-orientation of education in Latvia towards the strategy of sustainable development the content of education should be re-evaluated. Considering that ESD is more than formal information related to society, economy and environment, a teacher should also address skills, perspectives, values and the interrelationships between them (UNESCO, 2005a). Recently, it has been suggested that there is a fragmentation of acquired knowledge and skills, an overlap of material and a lack of systemic interaction between the acquired knowledge and skills in formal education in Latvia (Eglīis, 2004). Emphasis is still placed on the acquirement of the knowledge and skills characteristic to a particular subject on the school curriculum. Based on the gap between national strategic tendencies highlighted in Latvian National Development Plan 2007-2013 (LR Reǵionālās Attīstības un Pašvaldību Lietu Ministrija, 2006) and the actual situation in education, the reform of the educational content in schools has started. This reform acknowledges the skills pertaining to the practical application of information and the ability to express and to understand the use of the acquired information for further development. What is crucial in teacher education is that this reform be implemented in the process of teachers' training.

Geske, Grinfelds, Kangro and Zaķis (2003) assert that one-country or one-nation perspective can no longer be a comprehensive framework for education. Education should be "based on global values which allow for the analysis and access of any field of human activity in a global context" (p. 75). This is a strong suggestion to explore the historical and the current situation in education and to acknowledge its global dimension. To recover its position in society, education has to reclaim a global aim of education (Whitehead, 1929) and addresses issues that are meaningful to people, such as: questions of meaning, identity, to mention but a few.

\section{Reform of educational content}

Conceptual discourse about the content of education in Latvia is still rather implicit and is hiding among loud discussions about minority education, education quality, education management, paradigm change in education, etc. However, amid the aforementioned issues, some researchers observe the conflict that is created by school requirements to obtain specific theoretical knowledge on the one hand and labour market needs to master analytic 
skills, mobility and adjustment to new conditions on the other (Panina, 2007). It is pointed out that erudition and mental outlook does not include intellectual, creative, communicative and self-organisational skills (Lavrinenko, 2007) and that education should strike a balance between theoretical knowledge and the skills required to live in a real situation (Valbis, 2005). Although researchers insist that the success of an individual in $21^{\text {st }}$ century depends not only on the acquired knowledge, but also on creative thinking and acting that is "to use the acquired knowledge in a creative way, to be able to adapt to rapid changes in economics, politics and culture and, at the same time, to be able to initiate changes" (Rivža \& Krūzumētra, 2007, p. 7), the content of formal education does not become personally meaningful to a child, as what is mainly taught is knowledge - the sum of facts - without acknowledgement of its use in a particular situation (LR Valsts Kontrole, 2007, item 207). These aspects clearly represent the necessity of coherence of education content to societal needs.

Emphasising the lack of systemic interaction between the acquired knowledge and skills in formal education in Latvia (Eglītis, 2004), it has been suggested that there is a gap between theoretical/conceptual and practical/functional understanding of educational content. Briška and other educational researchers (Rubene, Briška, Klišāne, \& Maslo, 2006) examine this gap by discussing educational content in terms of competency as its analytical category. They share the notion that formal pre-school and school education practice and educational legislation is still based on understanding of competency as skill. This understanding created in the 70's and 80's infers an emphasis on the acquirement of knowledge and skills characteristic to a particular subject of the school curriculum. However, educational content in higher education grounded on obtaining a profession qualification reflects an understanding of competency as a qualification created in 80's and 90's (p. 46). Even if these two understandings are conceptually diverse, they share common failings: the fragmentation of acquired knowledge and skills, overlap of information covered by several subjects or study courses and lack of individualisation, to mention but a few. Finally, these two understandings lack a connection with the metacontent of education pertaining to the universal and core issue - a holistic, sustainable development of a person.

The practical solution to this imbalance has made it necessary to reform educational content that, according to Grīnuma (2005), has begun in schools from 1 September 2005 and is still ongoing. This reform, the second in the period since 1991, acknowledges the skills of a practical application of information, an ability to express oneself and to understand the use of the acquired information for further development. Content of education, as stated in the reformed school educational programmes, should be related not only to particular knowledge, skills and their practical use, but also to cultural and social experiences, experiences of faith, attitudes and values formation, experiences of emotions, culture and personality formation. However, even if one of the fundamental aims of the educational programmes is to promote pupil's responsible attitude towards himself/herself, family, society, surrounding environment and country, compulsory content that is included in the standards of any school subject mainly include thematic units and skills characteristic only to the particular subject (LR Valsts Kontrole, 2007, Item 206.5). Avoidance of the integration of attitudes as educational content in the standards of school subjects does not facilitate the holistic development of a child's personality and leads to the risk that this aim will not be achieved (Items 15.4.5, 216).

Attitudes are based on universal values and find their expression in the actions of the pupils and the teachers. Attitudes and values, in addition to knowledge and skills, are the fundamental components of educational content. They are the key concepts of pedagogy and the actual subject of education (Belickis, 2000). Attitude and value building provides 
not only the cross-curricular nature of education but also they imply a spiritual potential playing a crucial role in ensuring the continued existence of education as a system and as a process. Pedagogical discourse about this spiritual dimension of education (Belousa, 2000, 2002, 2003, 2005, 2006; Stakle, 2006) has been initiated with the decline of knowledgeoriented or pragmatic paradigms that determined its priorities in education over the last 30 years (Belousa \& Stakle, 2007; Stakle, 2006). According to this paradigm, knowledge based on its obviousness, its demonstrative nature and simplified economical evaluation of their acquirement have become the major components of educational content, partly excluding skills and replacing attitudes and values. Yet, knowledge compared to skills, attitudes and values is the simplest fundamental component of educational content and fills the lowest level in educational taxonomies. Moreover, the dominance of knowledge has caused an imbalance of knowledge-oriented educational content and of aims towards holistic development and value-oriented education.

\section{Content and metacontent of education}

The reform of educational content in Latvia so far lacks significant success. It has been discussed that the amount of information included in the standards and programmes should be reduced; standards and programmes should be made rather accessible and comprehensible not only to an educator who teaches the particular subject but also to pupils, their parents and other interested parties (Valbis, 2005). However, strategic activities to deal with overcoming the described imbalances and gaps are not initiated in state level.

One of the initiatives to explore the issue of educational content in a rather systemic way can be provided by educational theorists and researchers in terms of the discourse about the metacontent of education. The discourse regarding the metacontent of education should be initiated not only in order to develop awareness of two specific, yet interrelated, aspects of 'content' and 'metacontent', but also to promote the sharing and creation of practical ideas about development of values and attitudes in all the subjects of school and higher school curricula (Valbis, 2005). The word 'meta' has the Greek origin with the meaning 'beyond' or 'behind'. Consequently, metacontent issues provide a more comprehensive view/platform beyond the content of school subject. In order to ensure the successful acquirement of the content of each subject and study course metacontent issues should be interwoven across the content issues, integrated with the content. However, education quality nowadays has not yet been evaluated according to the acquired metacontent of education, that is the attitudes and values, either on an international or on a national level.

The metacontent of education has several dimensions - social, value, character, intercultural, spiritual that are widely discussed as contemporary perspectives of education theories, approaches and curriculum. Educators consider them to be embarrassing because metacontent issues are mainly abstract and complicated to compare. Yet, they can always be evaluated as they are expressed through one's action. Metacontent issues-based learning is a purposeful and conscious integration of the acquirement of knowledge and the development of skills, attitudes and values. Learning what integrates content and metacontent issues is rather more effective than knowledge acquirement-oriented learning (Belickis, 2000) for it is heading for the highest aim of education - personal and collective happiness (Noddings, 2003). 
Metacontent issues-based learning implies the following touchstones:

- Holistic understanding is a platform to view not only educational content (from several aspects, dimensions), but also a pupil, namely, his/her age, personality, ability and culture particularities that shape his/her learning, as the whole in its pedagogical understanding cannot be created by putting together separate parts.

- Spiritual interaction-based collaboration of all three components - pupils, teachers and the content that provides mutual balance, openness, tolerance towards diverse forms of expression and the spiritual enrichment of the pupil and teacher.

- Meaningful participation of both - pupil and teacher - that provides depth of individualization of the acquired content, breadth and creativity of its practical application. This meaningful participation facilitates pupil's active involvement in the implementation of positive changes, hence enabling development of his/her responsibility. Also, it ensures not only the professional but also the personal development of a teacher.

- Cross-curricular approach that urges a teacher to keep to the perspective beyond her/his subject and to encourage the application and value-based evaluation of each issue that is learned.

- Spiral perspective of teaching and learning that is the dynamic circular rotation of pupil's and teacher's interaction with educational content as opposed to the linear perspective based on sequential acquirement of content units by a pupil.

- Long-term strategy that increases not only the understanding and practical application of the learned/acquired content but also responsible participation in order to ensure the sustainability of the implemented changes.

A document about metacontent-related issues with significance to school education programmes and standards of school subjects would help teachers to surface this crucial topic at a conscious level. This document has to include a description of the absolute or universal values and the values related to the particular - national environment and specific period of time. This document should provide a discussion about teaching/learning, evaluation and research methods and strategies to integrate metacontent issues within educational content. Finally, examples of good practice also have to be included.

In higher education, the discussion about the metacontent of education can be reflected as the need both to introduce separate study courses on metacontent issues (for instance, sustainable development of education, intercultural and media dimension of education) and to reorient the content of existing study courses to address metacontent issues. Institutions of higher education that provide teacher training should face this challenge and implement a re-orientation of their study programmes and courses to address metacontent issues in a conscious and constructive way. Thus, both teacher trainers and teachers should admit the necessity for their further education.

\section{Intercultural and media literacy: Emerging issues of metacontent of education}

The process of globalisation has made an impact on changes not only in content but also in metacontent of education. One perspective on newly emerging issues is connected with the vast social and cultural environment in EU countries that has undergone significant changes 
in recent years. Membership in a European and global community has played a significant role in fostering conditions conductive to pluralism in the society. These changes have brought forward a discussion on issues of successful interaction in diverse multicultural environment. Education theorists also emphasise that the issue of intercultural education is of paramount importance in the twenty-first century (Banks \& McGee Banks, 2001) as it represents the current focus of educational controversy. It is recognised that there is a need for conceptual discourse of intercultural education consistent with both local realities and the broad European experience exploring the comparative view on various common and cross-cultural issues. Ethical issues of openness, sensitivity and tolerance to the broad diversity of culture and its incorporation in local educational settings in all EU countries, including Latvia, are some of the major concerns of intercultural education that should be approached in a rather personal and pupil-centred way.

In a global view, education disseminates the values and principles that are the basis of sustainable development. It is stated that education for sustainable development should highlight "the complexity and interdependence of three spheres, the environment, society - broadly defined to include culture - and the economy" (UNESCO, 2005b, 5). These trends have important implications for education (Banks \& McGee Banks, 2001) and should be treated in a culturally appropriate way. At its core, education for sustainable development is based on ideals and principles that form the fundamentals of sustainability, such as "intergenerational equity, gender equity, social tolerance, poverty alleviation, environmental preservation and restoration, natural resource conservation, and just and peaceable societies" (UNESCO, 2005c, p. 28). ESD increases civil capacity by enhancing and improving the workforce, social tolerance, environmental stewardship, participation in community-based decision-making and quality of life. Therefore, intercultural literacy is one of the issues that are emerging in education under the conditions of globalisation which has to be considered by educators because it implies education for life in a free and democratic society.

Although the vast conceptual discourse on intercultural education represents different perspectives, types of opinions and positions, their common ground is that intercultural education is not a curriculum, educational programme, school subject or a study course. It is pedagogical approach acknowledging diversity of learning and its benefits in all areas of human life. Intercultural education implies the potential to shape the society where humans with diverse cultural identities can co-exist and live successfully. Thus, intercultural education not only enables the shaping and development of a person's cultural identity, but also promotes equality and human rights, prevents discrimination and facilitates well-being, coherence and sustainable development of an individual and society. The prevalence and accessibility of media is another impact of globalization that changes the content and role of teacher education because the media "entertain us, socialize us, inform us, educate us, sell things to us (and sell us, as audience, to advertisers) and indoctrinate us - among other things. The media help shape our identities, our attitudes towards racial and ethnic minorities and our attitudes about sexuality" (Berger, 2003, p. 14). Cortes (2000) even argues that the mass media plays a role similar to school curriculum. Media provide a rich source of information as they educate more people about issues regarding society and culture than all other sources of education. McLaren (1998) also confirms that "pedagogy occurs not only in schools but in all cultural sites. The electronic media is perhaps the greatest site of pedagogical production that exists" (p. 297), and it can be considered a form of perpetual pedagogy.

Since 1960's and 70's, intercultural and media education are two of the most frequently discussed concepts in teacher education in Western Europe and America. The 
most significant reason for these discussions is that intercultural and media education are interdisciplinary concepts that change their constantly evolving meaning and overlap with social, economic and political tendencies in the globalised world. Several theorists observe that intercultural education and media education cannot be separated since they are complementary (Tyner, 1998; Pombo, 2003; Thomon \& Tessa, 2005). Both these types of education are based on the development of literacy, each in its own field.

Hirsch (1987) is one of the first authors who described the notion of cultural literacy. However, his understanding of cultural literacy is rather related to knowledge of the cultural symbols of the American white race than to a critical evaluation of cultural identity and search for intercultural connections. Heyward (2002) argues that intercultural literacy is rather extensive for it considers representatives of various cultures living together in a common space. He observes that the acquisition of intercultural literacy enables creating "a safe, sustainable and just global community" that promotes development of an open and tolerant society (p. 11). McLaren $(1995,1997)$ argues that the aim of intercultural education is to help students to explore the borders of their cultural identity, learn about their race, ethnicity, class and other keystones of identity and to understand other cultural identities. Heyward's (2002) multidimensional model of intercultural literacy implies six aspects: understanding, competencies, attitudes, participation, language proficiencies and identities. Several other authors (Bennett, 1998; Peterson, 2004; Chen \& Starosta, 2005) also argue about the aspects of intercultural literacy. Their suggestions about the components of intercultural literacy can be integrated into three interrelated components knowledge/understanding, skills/competencies and attitudes/values. These components that frame the foundations of intercultural literacy are particularly described in the suggestions part of the article.

Media literacy is traditionally understood as an ability to "gain access, analyse, evaluate and create messages in a variety of forms - from print to video to the Internet" (Thoman \& Tessa, 2005; Stakle \& Belousa, 2007, 2008). Carey (1988) argues that each aspect and product of mass media has its own cultural dimension. McQuail (2000) observes that media research has always been grounded in the broader culture-information field. Many theorists highlight that media educate people about their culture and social roles (Barry, 1997), promote the development of new forms and methods of communication (Burnett, 2004; Stakle \& Belousa, 2007, 2008; Stakle, 2008; Slevin, 2000) and enable a definition of sexual roles, culture codes, myths and patterns of social behaviour (Barry, 1997; Berger, 2003; Stakle, 2008). Burnett (2004) notes that the creation and communication of images is significant for any culture, and it is impossible to discover anything about social constructions of culture without reference to the culturally created images. Image creation is the way humans visualise themselves and communicate their constructed images (Burnett, 2004). Pombo (2003) asserts that issues of media education are always grounded in politics. For him, the understanding of media messages is based on personal experience, text analysis, political economy and self-reflection thus "the importance is not purely to know the different aspects of how media are constructed (for instance, lighting, sound), but how knowledge/meaning is constructed and interpreted within unequal relations in society" (p. 100). Consequently, as media literacy cannot be successfully acquired without intercultural literacy, intercultural literacy cannot be fully understood without using the knowledge and skills of media literacy.

Schools and universities cannot be neutral in terms of transferring social and cultural values and ways of behaviour expressed in attitudes. Issues of metacontent are always in educators' agendas either in explicit or implicit form (Banks, 2005). Intentional efforts to recognise intercultural and media literacy as metacontent issues and its public 
validation would represent responsible attitude and sustainable vision acknowledged by an educational institution.

\section{Teachers' view and experience of intercultural and media education in Latvia}

\section{Context of the study, the sample and data collection}

The current reality of education in Latvia occurs in the context of increased interest in the role of culture in society and the gradually emerging discussions, studies and methodological solutions of intercultural education at all its levels from kindergarten to university. Significant input to communicate urgent educational issues that are common to all of the European education area has also been contributed by the European Commission. One of the EU supported initiatives - Lifelong Learning programme Comenius 2.1 project "ICTime - ICT as a Tool of Intercultural and Media Education" (2006-2009) has provided an international platform with an aim of assisting teachers, students, teacher trainers and education policy makers by providing a methodology that enriches intercultural education by using digital media at schools. This part of the article implies the study about teachers' view and experience of intercultural and media education in the context of formal educational process at state schools in Latvia. This study was conducted in the first stage of the project by the team of researchers of the Institute of Sustainable Education that is a structural unit of Daugavpils University.

The population of the study consisted of general education teachers from state and municipality schools in Latvia. The sample of the study $(n=120)$ that included female $(n=98)$ and male $(n=22)$ teachers from 70 Latvian schools was selected according to the parameters of gender, age, work experience and location of the school. Respondents represented three age groups: 20-34 years old $(n=64), 35-54$ years old $(n=49)$ and 55-65 years old $(n=7)$. Respondents represented three work experience groups: up to 5 years $(n=39)$, from 6 to12 years $(n=42)$ and more than 12 years $(n=39)$. Respondents represented two groups according to location of their school: teachers from city schools $(n=80)$ and teachers from country schools $(n=40)$. According to the described criteria, the sample selected for the study represented the parameters that correlated to the main common characteristics of the population, keeping the ratio of gender, age, work experience and location of the school in connection with the latest statistical data (LR Izglitības un Zinātnes ministrija, 2009) that characterise the whole population of general (pre-school, basic and secondary) education teachers.

A questionnaire with 13 question groups each composed of 9-15 questions was created and used during the data collection. Two types of closed-ended questions were applied: multiple-choice questions to identify the respondents' attitude, opinion or experience and response scale questions to clarify degree of the respondents' position (agree, neutral and disagree). According to the content, the questions were relatively divided into two groups. The first group included questions about types and elements of culture, about content of intercultural education and tasks of intercultural educator, about the school subjects that ensured intercultural education, about children' age appropriate for development of intercultural skills, about teachers' own contribution and efforts of the whole school to the development of children intercultural skills and competencies. The second group included questions about media aids and technical devices teachers use in their educational practice, about school subjects where teachers used different media aids 
and technical devices, about the way and purpose teachers used different media aids and technical devices in educational practice and about the role of media in society. As an estimate to assess the internal consistency of a questionnaire Cronbach's $\alpha$ (alpha) was applied. The acquired alpha coefficient for each question group ranged from 0.70 to 0.82 and indicated that the generated instrument had an acceptable degree of reliability.

Regardless of the use of quantitative instrument, the collected data provided a rich descriptive insight into teachers' view and experience that expanded the scope of the comparative quantifications. Considering that qualitative data can be obtained by quantitative instruments (Myers, 2009; Tashakkori \& Teddlie, 1998) the collected quantitative data about teachers' view and experience were analysed inductively according to the themes that emerged from the data. As the authors of the article prefer descriptive presentation of the results, the discussion of the discovered situation is structured according to eight overlapping themes that emerged during the data analysis: types of culture, elements of culture; content of intercultural education; school subjects that imply intercultural education; intercultural education in the process of teaching and learning; the role of media in society; media message; cultural identity and the role of media in education. The further part of the paper provides an interpretation of the emerged themes discussing qualitative and quantitative connections between the data both, in the context study and in wider context of other studies about education and society in Latvia (Austers, Golubeva, \& Strode, 2007; LR Valsts Kontrole, 2007; Makarovs, 2006). Percentages in the following part of the paper provide information about the frequency of repeatable data in respondents' answers.

\section{Types of culture}

Identifying teachers' understanding of culture types, it was discovered that $77 \%$ of teachers agreed that nationality, ethnic identity and language are the essential hallmarks of culture. According to $40 \%$ of teachers, some factors, such as religious affiliation, moral health, social status, gender identity, economical status, place of residence, age and occupation, were considered to be insignificant. With regard to different conceptual understandings of culture, Welsh (Velšs, 2005) argues for two interpretations of culture - traditional and transcultural. For him, the traditional interpretation of culture implies a way of preserving its own identity and is grounded in ethnic affiliation and social homogenisation, and is based on detachment from the external influence. The teachers' view, according to the study, demonstrates that their understanding of culture is based on its traditional understanding.

Speaking about other types of culture, only $7 \%$ of teachers agreed that physical abilities were a significant cultural characteristic. Framing their opinion on gender identity, only $22 \%$ of teachers agreed that it was a type of culture, while $48 \%$ of teachers considered it insignificant and $30 \%$ disagreed that gender identity could be considered an important characteristic of culture. Several studies conducted in Latvia reveal a lack of tolerance in Latvian society regarding gender identity and sexuality. They indicate that "a considerable part of society is possibly ready to accept violence towards gay and lesbian persons" (Makarovs, 2006, p. 7). The study "Socio-economic development tendencies of Latvian cities" reveals that from $48 \%$ (Riga) up to $81 \%$ (Latgale region) of people would not wish to live next to homosexuals. Austers, Golubeva and Strode have discovered that "in Latvian schools, teachers do not attempt to prevent or solve conflicts where students suffer from a negative attitude of their classmates because of their differences. Students with different sexual orientations are most frequently subject to such risks" (Austers, Golubeva, \& Strode, 
2007, 14). Denying gender identity as a characteristic might result in neglecting the diverse learning styles of male and female pupils or avoiding various issues and conflicts related to gender role and sexual identity at school.

\section{Elements of culture}

Answering the question about elements of culture, $81 \%$ of teachers agreed that culture could be characterised by the following elements: everyday life, language, behaviour and manners, art, music and literature, traditions, values, attitudes and historical heritage. $40 \%$ of teachers considered that symbols, beliefs, norms, communication patterns, perception particularities and rituals are insignificant elements of culture. The collected data revealed controversies in teachers' views when they considered included traditions, but excluded rituals, included historical heritage but excluded cultural monuments, included behaviour and manners but excluded patterns of communication from the list of culture elements. This situation confirms teachers' traditional understanding of culture that emphasizes values of the so-called high or elitist culture. Although rituals are a part of traditions, understanding of ritual has been connected to traditions of pagan cults and is excluded from understanding of culture according to the elitist perspective. In general, historical heritage and cultural monuments share semantically similar meanings. Yet, in this study history and heritage are more considered to characterise elements of culture than cultural monuments that, according to the understanding of the high culture, indirectly indicate to non-spirituality and materialism.

The link between teachers' values and the hierarchical system of values characteristic of the epoch of modernism is revealed in their answers that behaviour and manners were considered to be rather inherent to culture than communication patterns. Although communication patterns include behaviour and manners, they are not identical. Noting behaviour and manners as significant elements of culture, teachers indirectly pointed out that formal aspect of communication was rather important to them than communication as a search for meaning. Educational process with adequate behaviour and manners as more important than meaningful communication is orientated towards a teacher-directed approach where discipline, recognition and effective reproduction of knowledge are preferred contrary to value orientation, attitude building, social skills development and identity formation.

\section{Content of intercultural education}

Sharing their view on the type of content which they considered to be related to intercultural education, $75 \%$ of teachers agreed that facts and knowledge about the traditions, history, lifestyle, geography and nature of different states, tolerance towards differences, interest in learning about differences, sharing different values, learning to cooperate and live together, an inclusive educational environment and support to every individual were significant elements of the content of an intercultural education. It confirms that teachers in general recognise the importance of intercultural issues that are included in school curricula and legislation that determine education in Latvia.

A rather detailed data analysis demonstrates that the recognition and prevention of stereotypes was considered an insignificant element of the content of intercultural education by $50 \%$ of teachers, whereas $86 \%$ of teachers considered the desire to preserve their culture as a significant aspect of intercultural education. Recognition and prevention of stereotypes is grounded in bias-free openness to others, creating a democratic environment for self- 
expression for everyone. Indicating that the recognition and prevention of stereotypes is insignificant, teachers $(46 \%)$ have indicated that their understanding of the content of intercultural education is insufficient and does not meet the diversity of cultural dimension in society. A considerable number of teachers $(85 \%)$ emphasised that a desire to preserve the particularities of their culture is a significant aspect of intercultural education. Although this position highlights a strong attachment to one's own culture, it is rather ethnocentric in character and exclusion-oriented in opposition to the cross-cultural approach that observes how different cultures interact with each other.

\section{School subjects that imply intercultural education}

$83 \%$ of teachers emphasised that school subjects of humanities, social, environmental science and arts were the most suitable for acquisition of content of intercultural education. $51 \%$ of teachers believed that intercultural education was insignificant in nature science and mathematics and $25 \%$ agree that natural sciences and mathematics were not suitable for intercultural education. A considerable number of teachers $(68 \%)$ pointed out that intercultural education should not be integrated in all school subjects. Teachers' answers highlight that the content of intercultural education implies specific knowledge (languages, traditions, geographical and environmental information, art and cultural monuments) that is acquired in a traditionally oriented educational process. However, intercultural education focused on development of attitudes and communicative skills can be integrated as metacontent in any school subject. To do this, educators have to change teaching strategies, providing equal opportunities for all pupils. Such educational approach would not aim to recognition and reproduction of knowledge. It would rather encourage a purposeful acquisition of social skills, non-discriminative attitudes and sustainability-oriented values.

\section{Intercultural education in the process of teaching and learning}

The greatest part of the teachers $(70 \%)$ believed that intercultural education was not merely the personal business of every individual. Teachers admitted that in general intercultural education should be purposefully organised and implemented in the educational process. The majority of teachers $(90 \%)$ agreed that the teacher should create an educational environment in which every pupil feels accepted and safe, introduce pupils to the languages, traditions and customs of all cultures present in the class, ensure equal treatment, rights and study opportunities for all pupils, enhance the presence of various cultures using extracurricular activities, promote tolerant attitude towards each other, model a positive attitude towards every culture, organise parents' involvement in cultural exchanges, teach students about mutual support and cooperation, promote the pupils' understanding of their own culture among other cultures, promote recognition of similarities and differences of various cultures and facilitate the formation of students' cultural identity. These statements illustrate the heart of intercultural education. Generally they indicate a teachers' point of view intercultural education has to be included in the educational process. However, only $17 \%$ of teachers admitted that they promoted the conscious and purposeful development of intercultural skills in their pedagogical activity. Half of the teachers stated that their pedagogical activity towards promoting development of intercultural skills was mainly unconscious $(55 \%)$, and some $(20 \%)$ pointed out that it was rarely possible to integrate intercultural skills within the content of the school subjects they taught. As the state does not provide sufficient support to integrate intercultural skills within the content of school subjects, half of the respondents $(57 \%)$ pointed out that 
intercultural educational depended solely on teacher's own initiative. The incompatibility of the teachers' rich understanding of the content of intercultural education and their poor contribution to include intercultural education in educational process gives rise to the tendency to give politically "correct" answers which fact has been one of the characteristic behavioural tendencies during the times when continuous changes are the constant reality of life.

\section{The role of media in society}

Nowadays, media play a significant role in the exchange of information in all aspects of human life. The exchange of information not supported by media is rather rare at the personal level of communication. An analysis of teachers' views on media reveals that 54\% of teachers emphasise the informative nature of media, noting that media provide information about the reality. However, a considerable portion of teachers $(52 \%)$ think that media are not the constitutive source of information. Likewise, only $30 \%$ of teachers indicate that media make the world to be smaller and more approachable, while more than half of teachers slightly disagree $(30 \%)$ and do not agree $(40 \%)$ with it. The teachers' view that media are an insignificant source of information suggest that teachers have to broaden their understanding about media, their roles and the various ways they are used in contemporary society.

$48 \%$ of teachers shared that the media communicate beliefs about unhealthy sexuality; while $51 \%$ of teachers emphasized that the role of media in sharing information about body culture is insignificant. Considering that teachers share a traditional understanding of culture that is based on the preservation of ethnicity and language, it becomes evident that notion that the media, as teachers believe, carry negative information about sexuality and body is not related to the understanding of body culture.

\section{Media messages and cultural identity}

Sharing their views about media message and its connection to the cultural identity of a person, $54 \%$ of teachers noted that media create stereotypes about minority cultures and advocate the ideology of the dominant culture. More than half of the teachers $(69 \%)$ claimed that media politicise the world and serve commercial purposes. $60 \%$ of teachers agreed that media degrade people while $40 \%$ of teachers disagreed with that premise. Only one third of teachers indicated that they use the media in order to promote intercultural competences while the same number of teachers insisted that they do not see media as a means to be applied as a tool of intercultural education. In general, the teachers' view highlights media as a threat to person's cultural identity. It could be one of the reasons why teachers do not actively integrate media expertise with the content of school subjects they teach.

\section{The role of media in education}

Sharing their view about school subjects where media can be used, $80 \%$ of teachers agree that media can be successfully used in humanities, social, environmental, nature sciences and teacher education. $70 \%$ of teachers agree that media should be used in all the subjects. In their teaching, the most used digital media were the Internet $(84 \%)$, audio teaching aids $(65 \%)$ and video (54\%). With regard to non-digital media, 95\% of teachers use books, pictures and maps, and $74 \%$ of teachers indicate that they use photos. Teachers' experience 
corresponds to contemporary tendencies that Internet has an ever-greater role in everyday life and education, merging several separate media (for instance, telephone, TV, radio, stereo) into one environment. However in general, a great portion of teachers are not aware of the fundamental use and circulation of media messages; they see media as more of a threat than as a tool of learning. Only $26 \%$ of teachers believe that media teach life skills, while most teachers slightly disagree $(36 \%)$ and disagree $(38 \%)$ with it.

$54 \%$ of teachers use media in the process of teaching to present the new material, while $28 \%$ use media only sometimes and $18 \%$ do not use media at all. Only $32 \%$ of teachers expect students to use media when doing their homework. It means that for teachers, the media facilitate their work and are not means for promoting mutual interaction and participation. The audit report "Implementation of general education system in accordance to the proposed aims" conducted by the State Audit Office reveals that out of 54 observed lessons only 2 characterised skilful use of the new information technologies (LR Valsts Kontrole, 2007, Item 237.4). Possibly, teachers lack the necessary skills for the successful use of media in teaching because $60 \%$ of teachers note that students use media during project weeks and $46 \%$ admit that students use media during pair and group work. By encouraging the use of media during project weeks and group work, teachers allegedly create educational space for students' free and creative expression in some parts of the teaching/learning process, allowing students to work creatively and to choose their own priorities. The fact that $70 \%$ of teachers believe that the main purpose of media in society is to provide entertainment leads one to hypothesise that project weeks and group work which are rarely used in the traditional teaching/learning process are considered as an entertaining part of it. During the lessons, teachers mainly use simple dialogical forms of interaction, i.e. teachers ask questions and pupils give answers (LR Valsts Kontrole, 2007, Item 237.1); only 9 out of 54 observed lessons involved group work (LR Valsts Kontrole, 2007, Item 237.3). Thus, it becomes clear why a considerable part of teachers view application of media differently in the contexts of teaching and learning. During teaching, teachers perceive themselves as leaders and consequently media function as facilitators of teacher's work - visual and audio presentations. In the context of learning, however, teachers do not consider it essential that students use media because it could complicate power control and require new competencies to understand and evaluate students' work.

\section{Summary}

This study highlights the fact that global processes and their relevance to everyday life constitute one of the most challenging issues for teachers. The study shows that there is a gap between teachers' intentions of what should be practiced in schools in terms of intercultural and media education and their educational initiatives. In general, the teachers' view and experiences of intercultural education reveal that their understanding of culture, of content and the implementation of intercultural education is grounded in an ethnocentric interpretation. Teachers connect the content of intercultural education mainly with humanities and social science. Their answers indicate that teachers do not fully understand the connection between intercultural education and the formation of attitudes in the educational process and, namely, its link with educational metacontent issues. Another point is that the majority of teachers do not organise activities that promote the development of intercultural skills consciously. Instead, they rely on an unconscious application of these skills in their pedagogical praxis that indicate shortcomings of their professional mastery in terms of adjusting their teaching to the situation presented in a globalised society. One of the main reason for the controversies in the teachers' view on 
culture and experience of teaching intercultural literacy is a lack of a coherent vision of intercultural education in Basic Education Standard and Basic Education Subjects' Standards (LR Izglìīības un Zinātnes ministrija, 2006), Secondary Education Standard and Secondary Education Subjects' Standard (LR Izglīīibas un Zinātnes ministrija, 2008), Basic Education Subjects' Curricula and Secondary Education Subjects' Curricula (available at http://isec.gov.lv/en/standards.shtml), also in education policy and research in Latvia.

Likewise, teachers' view of media and the use of media in teaching demonstrates an insufficient understanding of media literacy and poor experience of introducing media in education. In general, teachers consider the basic function of media to be entertainment and the main side-effect is a threat. It could serve as one of the reasons why teachers are not excited about the promotion of the development of media skills and are not aware of noncritical consumption of media messages.

The gap between teachers' intentions and experience discovered by the study urges teacher educators to approach intercultural and media education in a rather conscious way. Teacher education should serve as an essential agent of change. However, intercultural and media education is not yet entirely recognised as a quality standard for teacher education as well.

\section{Implementation intercultural and medial literacy as education metacontent issues}

Processes of globalisation and inclusiveness, increased technological development and the re-evaluation of human potential challenge traditional conceptions and narratives of society and confront educators with an unfamiliar reality that goes beyond individualism, dogmatism, indoctrination and hierarchical structure of organisation and fosters the development of whole fields of education. Historically, teachers and teacher trainers have always faced social and technological innovations. Teachers are also some of the first to encounter the dynamically changing intercultural and media contexts, since it is they who should either to be ahead of the times and adapt educational content and strategies to the needs of students or lose the social contact and correspondence of education to the needs of students.

Implementation of intercultural and media literacy as metacontent issues of education should be initiated by the re-evaluation of the four main concepts: multicultural identity; globalisation of culture; intercultural literacy and media literacy.

(1) Multicultural identity. Everybody is multicultural as multiculturalism is natural human experience. A person's cultural identity is shaped by his or her nationality or ethnical belonging, religion (belief, faith, position, system of spiritual values), language, gender or sexual belonging, age or generation, physical and mental exceptionalities (both learning difficulties and advanced performance), profession (occupation, business, engagement), residence (rural and urban), class (economical status, income level), education level, etc. These characteristics are the types of culture. People can identify themselves with several cultural types simultaneously. According to Heyward (2002), an interculturally literate person is one who acknowledges his or her own transcultural identity and is able to "shift between multiple cultural identities" (p. 17).

Cultural types can be both mutually compatible and exclusive. Cultural conditions of different countries result in different views of national identity. Thus, society is not a patchwork of fixed identities but a web of crosscutting identifications or as Welsh (Velšs, 
2005 ) puts it, "modern societies are multicultural and encompass a variety of life forms" (p. 243).

An argument that person's cultural identity can simultaneously be shaped by several types of culture has to be considered in terms of the variety of these types. Besides, some types of culture are more visible in the educational process than others. Therefore, educators' pedagogical mastery includes skills of ensuring equal possibilities and attitude, high expectations, purposeful support and a caring environment for pupils of all types in the educational process. Teachers have to learn how to recognise, honour and shape their teaching strategies to diverse cultural characteristics of pupils (Gay, 2000). Also, the voice of students should be considered as a source for learning.

(2) Globalisation of culture. Even if we speak about culture every day, it is rather challenging to grasp this notion. Conceptual understanding of culture represents it as a dynamic and complex process of meaning construction. Also, culture can be considered as a product of human creative activity.

In the present time any society, both global and national identity is multicultural. Cultural processes influenced by multiculturalism expand their traditional form, are enriched by different content and challenge their habitual meaning. The process of globalisation emphasises that no culture is authentic and self-sufficient (Stīgers, 2008). That is confirmed by a large scale of expansion of cultures, their mutual influence and the construction of new symbolic cultural expressions. Similarly, these changes initiate the development of critical theories on culture with an aim to interpret the ongoing processes.

According to Welsh (Velšs, 2005), we are living in a time when the traditional isolationbased structure of a culture is changing into transcultural structure. Thus, understanding of culture should overlook the dichotomised division into civilisation vs. nature, wide culture vs. subculture, high culture (literature, art, music, fashion) vs. low culture (mass, popular), open culture vs. closed culture, public culture vs. private culture. These understandings are homogeneous as they imply isolation, separation, inequality and polarity.

These two understandings are crucial for teachers as they have strong relevance for education. Educators have to consider that the traditional understanding of culture as ethnical affiliation is rather flat and politically tactless. If teaching to perceive, to understand and to interact with others is built on the traditional understanding of culture, such teaching facilitates a feeling of disconnectedness, insecurity or disrespect towards the unknown and the strange. Traditional understanding of culture does not encourage equal interaction in the environment where different communication styles, needs, norms and traditions are represented. The current expression of culture can be characterised by the processes of confluence, an interconnection that is beyond contrasts between one's own and other's. It provides a means for teachers to reconsider their understanding of culture (Austers, Golubeva, \& Strode, 2007).

The understanding of the concept "culture" should be based on a systemic approach that considers the complexity of society with all groups of a culture sharing their multiple perspectives and interacting together towards a common goal. Systemic thinking gives a rather detailed picture of reality. It emphasises the relationships between a system's parts, rather than the parts themselves fostering the best in human nature. Based on a systemic approach, the understanding of cultural constructions can be rather complex. According to Welsh (Velšs, 2005), cultural constructions can be differentiated both horizontally "regionally, socially and functionally different cultures, higher and lower, leading and alternative or scientific, technical, artistic, religious etc. cultures" and vertically "gender differences, for instance, interlace ethnic, class or professional cultures differences between female and male culture, homosexual, lesbian and gay trends" (p. 243). 
The systemic approach has become the widely accepted framework in education. This approach has a power and a potential to observe the connectedness of events, to see common patterns and their influence on pupils' actions and behaviours and to identify the needed supports and barriers to successful learning. It contributes to viewing an educational institution as a complex interconnected set of relationships that create a unique identity and culture. Thus, the vision provided by a whole-system approach initiate not just practical changes but a shift in attitudes.

Each type of culture has its own cultural elements that can be transferred from generation to generation. They can be both invisible/implicit and visible/explicit. Visible elements are closely connected with the behaviour. They are rituals (ceremonies, festivals that implement values and norms) and different ways we interact with each other. Institutions (social structures that implement values and norms), heroes (real or fictitious characters who are models of culture), artefacts (things or material objects that are visual, observable products of a human activity) also belong to the group of visual elements. However, the essence of culture is not in the artefacts and other tangible elements (Banks \& McGee Banks, 2001). The essential elements of culture are invisible and intangible. Culture essentially consists of symbolic or ideological elements that imply values, norms and attitudes. Both of the elements, as well as the tangible cultural elements and the way people perceive, interpret and use them are mutually interrelated.

For educators, this subtle area is rather challenging. Teaching and exploring all cultural elements requires a genuine awareness of cultural aspect in general. Some elements constitute more significant belonging to the particular culture than others. Some of the elements are easier to be taught. Teaching of cultural elements differs in each educational situation. The metaphor of an iceberg or an onion is widely used by educators as a visual interpretation of interrelatedness of invisible/implicit and visible/explicit cultural elements. Thus, culture can be represented by the elements seen "above the water" that are supported with more subtle elements lying "under the water".

(3) Intercultural literacy. Foundations of intercultural literacy are framed by three interrelated components - (1) knowledge and understanding; (2) skills and competencies; (3) attitudes and values.

1. The first component of intercultural literacy is knowledge and understanding about own culture, about other cultures especially those that we encounter in our daily life, about interaction of culture and other dimensions of human activity education, politics and about legislature connected with culture - human rights and duties, etc. This component sends the message that we all perceive things, think and act in a different way. Reflection on these issues from the perspective of diversity also encourages critical self-evaluation.

2. The second component of intercultural literacy is skills and competencies to apply knowledge and understanding in practice: the recognition of a multicultural situation (awareness that diverse opinions about one and the same thing can be present, diverse behaviours, recognition of one's own culture among other cultures, recognition of one's own and other's uniqueness,...), intercultural communication skills (ability to communicate in the environment where different communication styles, needs, norms, traditions are represented; an ability to listen,...), intercultural interaction skills (equal/non-hierarchical, non-prejudiced interaction and cooperation, mutual benefit,...), flexible behaviour (taking risk, overcoming insecurity, adjustment to unknown conditions,...) and critical analysis of multicultural situation. 
3. The third component of intercultural literacy is values and attitudes: awareness of own multilateral cultural belonging and identity, approval of multicultural situation, respect towards the unknown and the strange, openness to diversity, empathy, tolerance, inclusion, sensitivity, joy of exploration and creativity. Being self-critical, a pupil is able to recognise his/her patterns of thinking, attitude and behaviour are mainly socially and culturally learned. Global ideas about the truth are also socially and culturally constructed.

Intercultural literacy that is both the content of intercultural education and metacontent of education should be taught to a child firstly by her/his parents and other family members, but not mainly, as it is considered by teachers (Austers, Golubeva, \& Strode, 2007). Briška and other education researchers (Rubene, Briška, Klišāne, \& Maslo, 2006) highlight that intercultural literacy (sociocultural competency) represent the strategic aim of education and should be introduced in education standards and programmes. Their model of learning-based educational standards clearly implies an intercultural dimension of metacontent in a pre-school, school, professional and higher education setting as it is equally the responsibility of both family and formal education at schools and universities.

The teacher's individual attempt to implement intercultural education requires her/his strong position, motivation and courage. Implementing all three components in education, teachers should move from an essentialist understanding of the curriculum to a more constructive one where pupils' critical thinking is encouraged (Valbis, 2005). However, success initiated by the whole-school approach will be rather more effective than changes that take place in a single classroom by an isolated teacher. Values should become words and actions that have to be reinforced until they are integrated in school's culture.

(4) Media literacy. Foundations of media literacy are formed by skills to gain access, analyse, experience and create media messages and/or products in different media environments, forms and contexts. Media literacy is the ability combined of (1) skills of producing media messages and (2) skills of critical viewing media.

1. Production of media messages implies skills of media message creation either individually or participating in networks. It is applicable to all media. Media message creation can also be a means of self-expression. Thus, joy of creation, exploration and discovery are significant motivators in creating media messages. Skills in producing media messages can be acquired either separately or together with skills in viewing media messages critically.

2. Critical viewing of media implies skills that encourage questioning about what is seen and heard in media, about the composition of media messages, about the intended content of media message and its difference from the delivered content, about interactivity of media messages and their role in a particular cultural context, about the benefits acquired from the creation of the particular media message and the owners of the benefits, about the mechanisms of public and commercial relations and propaganda hidden in media messages. Critical viewing of media also includes the skill to manage one's own use of media.

Media are a part of the everyday life of young people, so the use of digital media as a learning tool provides extra motivation for pupils and is based on their interests and everyday realities (Stakle \& Belousa, 2007; Stakle, 2008). Pupils are enthusiastic consumers of information provided by media, and the classroom can be an excellent place to discuss and deconstruct biases, stereotypes and destructive images of cultural groups. Digital technologies can stimulate innovative solutions to traditional problems and support 
learning. Thus, digital media in education determine the focus on values, attitudes, critical thinking and consciousness rising of students rather than simply on knowledge acquisition. It is clear that pupils are often more competent than their teachers in the technical use of media and are more often involved in multicultural situations. Teachers ought not to compete with media environment or avoid using it but rather promote the inclusion of media and intercultural literacy in educational process, thus promoting the correspondence of teaching and learning to contemporary social, cultural and technological reality.

If teachers do not introduce critical reading of media messages in their teaching and accept the situation where pupils' attitudes regarding media messages are formed by media environment and/or non-formal education, media messages could become an essential drive shaping pupils' attitude building and value orientation. The personality whose attitudes and values have developed under the influence of media is open for noncritical consumption of media message environment. Thus, formal education should provide an opportunity to acquire media literacy that promotes formation of attitudes and values in a meaningful learning, encourages perceiving interconnection between everyday life, entertainment and education and accepting responsibility for pupils' daily choices made in media environment.

Media literacy is one of the abilities among print, numeral and technological literacy that nowadays characterises a literate person. Media literacy development is an ongoing process that constantly evolves. Media literacy acquisition should be approached from a constructivist framework that is the core of a pupil-centred approach and implies an engagement of pupils in active construction and transformation of their own learning process and outcomes rather than in instrumental, passive and value-neutral transmission of information. Thus, constructivism is considered as an epistemology that encourages pupils to be actively involved in construction and reconstruction of their knowledge, attitude and actions in a culturally sensitive educational environment. Implementation of this epistemology is based on learning from rather than learning about, highlights collaboration and supports cultural sensitivity of both teachers and pupils.

Although these concepts - multicultural identity, globalisation of culture, intercultural literacy and media literacy - are described mainly in terms of metacontent of education, to provide for their sustainable implementation they should also be addressed in a vision, mission and policy statements, staff development and education methodology, education materials and monitoring/evaluation of education.

Implementation of the described concepts in teacher education can be started with identifying issues of metacontent that characterise or are related to the particular study course or study program. Afterward, the content of the study course has to be restructured by highlighting metacontent issues and integrating them with content issues into meaningful units. Intercultural and media issues in teacher education are approached from a constructivist and transformative framework that form the core of a pupil-centred approach and imply an engagement of students in active construction and transformation of their own learning process and outcomes rather than in instrumental, passive and value-neutral transmission of information. Thus, constructivism and transformation serve as epistemologies that encourage pupils to be actively involved in challenging, construction and reconstruction of their knowledge, attitude and action in a culturally sensitive educational environment. Implementation of these epistemologies is based on learning from rather than learning about, highlights collaboration and supports cultural and media sensitivity of both teacher educators and pupils. 


\section{Conclusion}

Both intercultural literacy and media literacy are inseparably related and interactively evolving on a common path to raise global awareness and knowledge on worldwide issues. Intercultural and media literacy as education metacontent issues share common scope with several current educational perspectives, such as, Education for Sustainable Development, Human Rights Education, Education for Peace and Justice, Citizenship Education, Intercultural and Interfaith Education, Development Education and Global Education.

Considering intercultural and media literacy as metacontent issues of formal education even if it is recognised throughout preschool and including higher education, is merely an incomplete contribution to ensure sustainable functioning of society in the era of globalisation. To create inclusive and open environment in society, all three types of education, formal, non-formal and informal have to consider the issues of intercultural and media literacy as a priority of educational content and policy. Moreover, both governmental and non-governmental sectors have to assume equal responsibility and involvement in its implementation. Multi-disciplinary vision and action to increase understanding about urgent intercultural issues, such as tolerance, equality, inclusion, and to encourage interculturally and media literate co-existence and cooperation of individuals and organisations should be particularly promoted.

Latvian national development plan 2007-2013 (LR Regionālās Attīstības un Pašvaldību Lietu Ministrija, 2006) recognizes education as the most important factor to increase the quality of life that is the goal of the country's growth. An educated and creative personality is considered to be the main driving force and beneficiary of this development because human knowledge, intellect and its practical application are the country's key development resource. The national growth model "People First" is based on humancentred approach where the main strategic principles are inclusion, networking, balancing of development and reduction of isolation. It is rather significant that this plan underlines several turning points; one of them is a turning point in attitude that can be reached by education that recognises metacontent issues.

\section{References:}

Austers, I., Golubeva, M., \& Strode, I. (2007). Skolotāju tolerances barometrs [Teachers' barometer of tolerance]. Retrieved March 23, 2008, from http://www.politika.lv/index.php?id=14838

Banks, J. A. (2005). Multicultural education: Characteristics and goals. In J. A. Banks, \& C. A. McGee Banks (Eds.), Multicultural education: Issues and perspectives (5th ed., pp. 3-30). New York: Allyn and Bacon.

Banks, J. A., \& Mc Gee Banks, C. A. (Eds.). (2001). Multicultural education: Issues and perspectives (4th ed.). New York: John Wiley \& Sons.

Barry, A. M. S. (1997). Visual intelligence: Perception, image, and manipulation in visual communication. Albany, NY: State University of New York Press.

Belousa, I. (2000). Spirituality in education: Comparison of its modern and postmodern understanding. In Proceedings of the second international conference "Person. Color. Nature. Music.”, 18-19 May 2000 (pp. 68-71). Daugavpils University.

Belousa, I. (2002). Sustainable education and spirituality in the university: Looking for a way of complementation. Journal of Teacher Education and Training, 1, 3-12.

Belousa, I. (2003). Possibilities of defining and awakening of spirituality in the university: Qualitative review. In Proceedings of the first international JTET conference 
“Sustainable development. Culture. Education.", 11-14 May 2003 (pp. 67-77). Daugavpils University.

Belousa, I. (2005). Spirituality as a dimension of education: Reimaging and reconstructing teacher education in Latvia. Unpublished doctoral dissertation, Fordham University, New York.

Belousa, I. (2006). Defining spirituality in education: Post-soviet perspective. In M. de Souza, K. Engebretson, G. Durka, R. Jacksonm, \& A. McGrady (Eds.), International handbook of the religious, spiritual and moral dimensions of education (pp. 215-230). Dordrecht: Springer.

Belousa, I., \& Stakle, A. (2007). Development and reorientation of education toward sustainability in Latvia after 1991. In A. Pipere (Ed.), Education and Sustainable Development: First Steps toward Changes (Vol. 2, pp. 99-113). Daugavpils: Daugavpils University Academic Press "Saule".

Belickis, I. (2000). Vērtīborientēta mācību stunda [Value-oriented class]. Riga: RaKa.

Bennett, M. J. (Ed.). (1998). Basic concepts of intercultural communication. Yarmouth, ME: Intercultural Press.

Berger, A. A. (2003). Media and society: A critical perspective. Oxford: The Rowman \& Littlefield Publishing Group.

Burnett, R. (2004). How images think. Cambridge, MA: Massachusetts Institute of Technology Press.

Carey, J. W. (1988). Media myth and narratives. Thousand Oaks, CA: Sage.

Chen, G., \& Starosta, W. J. (2005). Foundations of intercultural communication. Lanham, MD: University Press of America.

Cortes, C. E. (2000). The children are watching: How the media teach about diversity. New York \& London: Teachers College Press.

Eglītis, Z. (2004). Kurp ej, Latvijas izglītības sistēma? [Where are you going, the system of Latvian education?] Diena [Day], 10 July, 2.

Gay, G. (2000). Culturally responsive teaching: Theory, research, and practice. New York: Teachers College Press.

Geske, A., Grinfelds, A., Kangro, A., \& Zaḳis, J. (2003). Pre-service training in higher education. In I. Dedze, S. Heyneman, \& G. Catlaks (Eds.), Education in Latvia's transition: The challenge of management. Report on education in Latvia 2001/2002 (pp. 74-87). Riga: AGB.

Grīnuma, I. (2005). Definīciju iekalšanai sola beigas [The promised end for the definition memorizing] Diena [Day], 27 January, 4.

Heyward, M. (2002). From international to intercultural: Redefining the international school for a globalized world. Journal of Research in International Education, 1, 9-32.

Higher Education Council. (2001). National conception on the development of Latvian higher education and higher educational institutions for the period until 2010. Retrieved September 17, 2009, from http://www.aip.lv/koncept_doc_nac_koncep .htm

Hirsch, E. D., Jr. (1987). Cultural literacy: What every American needs to know. Boston: Houghton Mifflin.

Lavriṇenko, O. (2007). Zināšanu sabiedrība: Ģimenes pozīcija [Knowledge society: Family position] In Izglītība zināšanu sabiedrības attīstībai Latvijā: Zinātniski pétnieciskie raksti 2(13) [Education for the development of knowledge society in Latvia: Scientific Articles 2(13)] (pp. 216-224). Rīga: Zinātne. 
LR Izglītības un Zinātnes ministrija. (2006). Noteikumi par valsts standartu pamatizglītībā un pamatizglìtības mācību priekšmetu standartiem [Regulations on national basic education standard and basic education subjects' standards]. Retrieved September 20, 2009, from http://izm.izm.gov.lv/upload_file/Izglitiba/Vispareja_izglitiba/ Direktora_gramata/39_MK_Nr.1027_Pamatizgl_standarts_291206-2.doc

LR Izglītības un Zinātnes ministrija. (2008). Noteikumi par valsts vispārējās vidējās izglìtības standartu un vispārēejās vidējās izglītības mācību priekšmetu standartiem [Regulations on national general secondary education standard and secondary education subjects' standards]. Retrieved September 20, 2009, from http://izm.izm.gov.lv/upload_file/Izglitiba/Vispareja_izglitiba/MK_noteikumi_nr_ 715.doc

LR Izglītības un Zinātnes ministrija. (2009). Statistika par vispārējo izglītību [Statistics about general education]. Retrieved September 20, 2009, from http://izm.izm.gov.lv/registri-statistika/statistika-vispareja/3334.html

LR Reǵionālās Attīstības un Pašvaldību Lietu Ministrija. (2006). Latvian national development plan 2007-2013. Retrieved September 20, 2009, from http://www.nap.lv

LR Valsts Kontrole. (2007). Vispārējās izglītības sistēmas realizācija atbilstīgi izvirzìtajiem mērķiem [Implementation of general education system in accordance to the proposed aims]. Retrieved September 20, 2009, from http://www.lrvk.gov.lv/index.php?id=1759

Makarovs, V. (2006). Latvijas iedzīvotāju attieksme pret seksualajām minoritātēm: Dimensijas un "temperatūra" [Attitude of Latvians to sexual minorities: Dimensions and "temperature"]. Rīga: Sorosa fonds - Latvija.

McLaren, P. (1995). Critical pedagogy and predatory culture: Oppositional politics in a postmodern era. New York: Routledge.

McLaren, P. (1997). Revolutionary multiculturalism: Pedagogies of dissent for the new millennium. Boulder, CO: Westview Press.

McLaren, P. (1998). Education as a political issue. In H. S. Shapiro, \& D. E. Purpel (Eds.), Critical social issues in American education: Transformation in a postmodern world, (2nd ed., pp. 289-298). Mahwah, NJ: Lawrence Erlbaum Associates.

McQuail, D. (2000). Mass communication theory (4th ed.). London: Sage.

Myers, M. (2009). Qualitative research in business \& management. London: Sage.

Noddings, N. (2003). Happiness and education. New York: Cambridge University Press.

Paṇina, L. (2007). Izglīî̉bas kvalitātes elementi izglīîibas sistēmā iesastīto grupu vērtējumā. In Izglìtība zināšanu sabiedrības attīstībai Latvijā: Zinātniski pētnieciskie raksti 2(13) [Education for the development of knowledge society in Latvia: Scientific articles 2(13)] (pp. 52-73). Riga: Zinātne.

Peterson, B. (2004). Cultural intelligence. Boston, MA: Intercultural Press.

Pombo, T. (2003). Video production in Ohio schools: The role of media pedagogy in youth identity. Unpublished doctoral dissertation, Ohio University, Athens (the USA).

Rauhvargers, A. (2003). Latvia in Bologna process: Report on the reforms in Latvia's higher education on the way towards European higher education area. Riga: Latvian Rector's Council, Academic Information Centre. Retrieved September 24, 2009, from http://www.aic.lv/rec/Eng/new_d_en/bologna/default.htm

Realising the European Higher Education Area. (2003). Communiqué of the conference of ministers responsible for higher education. Berlin, September 19. Retrieved September 24, 2009, from http://www.aic.lv/rec/Eng/new_d_en/bologna/Berl_ comm_fina.pdf 
Rivža, B., \& Krūzumētra, M. (2007). Ievads [Introduction]. In Izglītība zināšanu sabiedrības attīstībai Latvijā: Zinātniski pētnieciskie raksti 2(13) [Education for the development of knowledge society in Latvia: Scientific articles 2(13)] (pp. 5273). Rīga: Zinātne.

Rubene, Z., Briška, I., Klišāne, J., \& Maslo, I. (2006). Plaisa kompetences izpratnē teorijā un praksē [Gap in understanding of competency in theory and practice]. In I. Maslo (Ed.), No zināšanām un kompetentu darb̄̄bu: Mācīšanās antrpologiskie, ètiskie un sociālkritiskie aspekti [From knowledge to competent activity: Anthropological, ethical, and social-critical aspects of learning] (pp. 45-57). Rìga: LU Akadēmiskais apgāds.

Slevin, J. (2000). The internet and society. Cambridge: Polity Press, Blackwell Publishers.

Stakle, A. (2006). Attitude towards teaching and learning in the context of students' educational philosophy. In A. Pipere (Ed.), Education and Sustainable Development: First Steps toward Changes (Vol. 2, pp. 368-380). Daugavpils: Daugavpils University Publishing House "Saule".

Stakle, A., \& Belousa, I. (2007). Media in reorienting art education towards sustainability. In Proceedings of the $V$ international conference "Person. Color. Nature. Music.”, 17-21 October 2007 (pp. 151-158). Daugavpils: Daugavpils University.

Stakle, A., \& Belousa, I. (2008). Blending media and intercultural dimensions of teacher education. In Proceedings of the international APERA conference "Educational research for innovation and quality in education: Policy and pedagogical engagements across contexts”. Singapore: National Institute of Education, http://www.apera08.nie.edu.sg/proceedings/6.20.pdf

Stakle, A. (2008). The role of media in creating a meaningful learning environment in art education: The case of young artists organizations in Daugavpils. Collection of articles of the 6th international JTEFS conference "Sustainable development. Culture. Education.", 4-7 June 2008 (pp. 658-667). Eskisehir, Turkey: Anadolu University.

Stīgers, M. (2008). Globalizācija: L̦oti saistošs ievads [Globalization: A very short introduction]. Riga: Satori.

Tashakkori, A., \& Teddlie, C. (1998). Mixed methodology: Combining qualitative and quantitative approaches. Thousand Oaks, CA: Sage.

Thoman, E., \& Tessa, J. (2005). Literacy for the 21st century: An overview \& orientation guide to media literacy education. Part I: Theory. Retrieved October 20, 2009, from http://www.medialit.org

Tyner, K. (1998). Literacy in a digital world: Teaching and learning in the age of information. Mahwah, NJ: Lawrence Erlbaum Associates.

UNESCO. (2005a). Guidelines and recommendations for reorienting teacher education to address sustainability. Paris: UNESCO. Retrieved October 20, 2009, from http://unesdoc.unesco.org/images/0014/001433/143370E.pdf

UNESCO. (2005b). Promotion of a global partnership for the UN Decade of Education for Sustainable Development (2005-2014): International implementation scheme for the decade in brief. Paris: UNESCO.

UNESCO. (2005c). United Nations decade of education for sustainable development (2005-2014): International implementation scheme. Paris: UNESCO.

Valbis, J. (2005). Skolēna personības attīstība - izglītības virsuzdevums [Personality development of a pupil - a principal task of education]. Rīga: Zvaigzne ABC.

Velšs, V. (2005). Estētikas robežceļi [Crossroads of aesthetics]. Riga: Laikmetīgās Mākslas centrs. 
Whitehead, A. (1929). The aims of education and other essays. New York: The Free Press.

\section{Acknowledgement:}

Alnis Stakle acknowledges that his contribution to this study was supported by ESF project "Support to Implementation of Doctoral Studies at Daugavpils University", agreement No. 2009/0140/1DP/1.1.2.1.2/09/IPA/VAA/015.

\section{Correspondence:}

Inga Belousa, $\mathrm{PhD}$, Institute of Sustainable Education, Faculty of Education and Management, Daugavpils University, Parādes Street 1, Daugavpils, LV-5401, Latvia. Email: inga.belousa@du.lv 